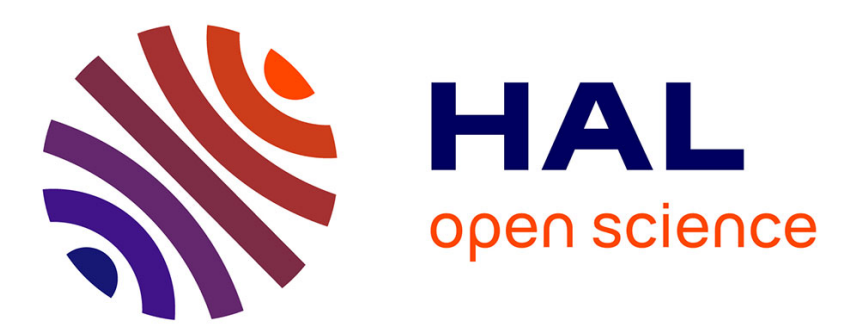

\title{
Influence of vanadium on structure, mechanical and tribological properties of $\mathrm{CrN}$ coatings
}

Linda Aissani, Corinne Nouveau, Michael J. J Walock, Hamid Djebaili, Ahmed Daoud Djelloul

\section{- To cite this version:}

Linda Aissani, Corinne Nouveau, Michael J. J Walock, Hamid Djebaili, Ahmed Daoud Djelloul. Influence of vanadium on structure, mechanical and tribological properties of CrN coatings. Surface Engineering, 2015, 31 (10), pp.779-788. 10.1179/1743294415Y.0000000043 . hal-01530960

\section{HAL Id: hal-01530960 https://hal.science/hal-01530960}

Submitted on 18 Dec 2017

HAL is a multi-disciplinary open access archive for the deposit and dissemination of scientific research documents, whether they are published or not. The documents may come from teaching and research institutions in France or abroad, or from public or private research centers.
L'archive ouverte pluridisciplinaire HAL, est destinée au dépôt et à la diffusion de documents scientifiques de niveau recherche, publiés ou non, émanant des établissements d'enseignement et de recherche français ou étrangers, des laboratoires publics ou privés. 


\title{
Influence of vanadium on structure, mechanical and tribological properties of $\mathrm{CrN}$ coatings
}

\author{
L. Aissani*1 ${ }^{1}$, C. Nouveau ${ }^{2}$, M. J. Walock ${ }^{3}$, H. Djebaili ${ }^{4}$ and A. Djelloul ${ }^{4}$
}

This work aims to show the characterisation of $\mathrm{Cr}-\mathrm{V}-\mathrm{N}$ coatings, with the varied amounts of $\mathrm{Cr}$ and $\mathrm{V}$. CrN, VN and $\mathrm{Cr}-\mathrm{V}-\mathrm{N}$ coatings were deposited onto silicon and XC100 steel substrates by reactive radio frequency magnetron sputtering and characterised with $\mathrm{X}$-ray diffraction, $\mathrm{X}$-ray photoelectron spectroscopies, energy dispersive X-ray spectroscopy, scanning electron microscopy, nanoindentation, pin on disc tribological tests and scratch tests. The residual stress was calculated using the Stoney formula. Compared to the CrN system, the Cr-V-N films presented a rough surface based on pyramidal morphology. A hardness of $19.53 \mathrm{GPa}$ and a friction coefficient of 0.55 were obtained for $\mathrm{CrN}$; in contrast, $\mathrm{Cr}-\mathrm{V}-\mathrm{N}$ coatings presented a weak hardness of $6.23 \mathrm{GPa}$. In the case of wear against a 100Cr6 ball, the $\mathrm{Cr}-\mathrm{V}-\mathrm{N}$ films were completely removed from the substrate, even though the $\mathrm{Cr}-\mathrm{V}-\mathrm{N}$ coating presented a low friction coefficient (0.39). However, the VN film showed good tribological performance.

Keywords: Cr-V-N, CrN, VN, Hardness, Wear, Friction coefficient

\section{Notation:}

$\begin{aligned} \text { at.- } \% & \text { atomic percentage } \\ \mathrm{Ar} / \mathrm{N}_{2} & \text { (argon/nitrogen) gases } \\ \mathrm{B} & \text { the line width (FWHM) in radians } \\ \mathrm{D} & \text { grain size } \\ \mathrm{E} & \text { Young's modulus } \\ e_{\mathrm{f}} & \text { film thickness } \\ e_{s} & \text { substrate thickness } \\ E_{\mathrm{s}} & \text { Young's modulus of the substrate } \\ \mathrm{eV} & \text { electron volt } \\ d & \text { diameter } \\ H & \text { hardness } \\ \mathrm{Hz} & \text { Hertz } \\ L \mathrm{c}_{1} & \text { cohesive failure critical load } \\ L \mathrm{c}_{2} & \text { adhesion failure critical load } \\ \mathrm{N} & \text { Newton } \\ P & \text { pressure } \\ R & \text { curvature radius of the sample after } \\ & \text { deposition } \\ R_{0} & \text { curvature radius before deposition } \\ \mathrm{Ra} & \text { average roughness } \\ R_{\mathrm{RMS}} & \text { root mean square roughness } \\ \mu & \text { friction coefficient }\end{aligned}$

${ }^{1}$ Université de Djijel, Cité Ouled Aissa, BP 98, 18000 Jijel, Algérie ${ }^{2}$ LaBoMaP, Arts et Métiers ParisTech, Rue Porte de Paris, 71250 Cluny, France

${ }^{3}$ Department of Physics, University of Alabama at Birmingham, $\mathrm{CH} 310$, 1720 2nd Ave S, Birmingham, AL 35294-1170, USA

${ }^{4}$ LASPI, Université de Khenchela, Rue de Batna, 4000 Khenchela, Algérie

*Corresponding author, email lindaaissani2004@yahoo.fr $\lambda_{\text {Co }}$ X-ray wavelength of cobalt

$\theta$ Bragg's angle

$\sigma$ the residual stress

$v_{\mathrm{s}}$ Poisson's ratio of the substrate

\section{Introduction}

Many studies have been dedicated to $\mathrm{Cr}$ based ternary nitrides, such as $\mathrm{Cr}-\mathrm{Al}-\mathrm{N}^{1}$ and $\mathrm{Cr}-\mathrm{Zr}-\mathrm{N} .^{2}$ These compounds have been developed rapidly, and their excellent properties (high oxidation resistance and a very low surface roughness, compared to the $\mathrm{Cr}-\mathrm{N}$ system) were reported in many papers. Typically, the tertiary elements that have been chosen are based on the properties of the binary systems.

The addition of $\mathrm{V}$ to improve the tribological properties of $\mathrm{CrN}$ films has been studied successfully. ${ }^{3}$ In addition, the excellent mechanical properties were achieved for CrN/VN multilayers deposited by magnetron sputtering. ${ }^{4}$ Recently, vanadium nitride has generated a great deal of interest because it can easily oxidise at high temperatures and become a good lubricant film. ${ }^{5,6}$ The coefficient of friction of a $\mathrm{Cr}-\mathrm{V}-\mathrm{N}$ coating, with a hardness of $15 \mathrm{GPa}$, was $0 \cdot 5$ when sliding against AISI 52100 steel at a room temperature, according to Uchida et al. ${ }^{7}$ Moreover, the coefficient of friction of $\mathrm{Cr}-\mathrm{Al}-\mathrm{V}-\mathrm{N}$ coatings sliding against the same steel decreased from $0 \cdot 6$ at the room temperature to 0.05 at $800^{\circ} \mathrm{C}$ due to the formation of vanadium oxides. ${ }^{8}$ When vanadium is mixed with other transition metal nitrides like $\mathrm{CrN}$ or $\mathrm{TiN}^{3}$ the tertiary compound can at present improve mechanical properties comparing the constituent binary materials. For example, the ternary $\mathrm{Cr}_{50} \mathrm{~V}_{50} \mathrm{~N}$ nitride shows a sliding performance instead of 
the binary $\mathrm{CrN}$ and $\mathrm{VN}$ systems. ${ }^{7} \mathrm{Ti}_{77} \mathrm{~V}_{23} \mathrm{~N}$ shows a higher hardness in comparison to the binary $\mathrm{TiN}$ and $\mathrm{VN}$ systems, while $\mathrm{Ti}_{22} \mathrm{~V}_{78} \mathrm{~N}$ had a lower hardness comparing to the binary TiN system. ${ }^{9}$

The purpose behind the present work is to study the properties of $\mathrm{Cr}-\mathrm{V}-\mathrm{N}$ films deposited by reactive radio frequency (RF) magnetron sputtering. Thus, the ternary $\mathrm{Cr}-\mathrm{V}-\mathrm{N}$ films are compared to the binary $\mathrm{CrN}$ and $\mathrm{VN}$ coatings. By this comparison, the influence of vanadium content on the structure, morphology, mechanical and tribological properties of the $\mathrm{Cr}-\mathrm{N}$ system can be determined.

\section{Experimental}

$\mathrm{Cr}-\mathrm{V}-\mathrm{N}$ thin films were deposited by $\mathrm{RF}$ magnetron sputtering (NORDIKO type $3500,13.56 \mathrm{MHz}$ ) in an $\mathrm{Ar} / \mathrm{N}_{2}$ mixed atmosphere on $\mathrm{Si}$ (100) coupons $\left(10 \times 10 \mathrm{~mm}^{2}, 380 \mu \mathrm{m}\right.$ thick $)$ and polished XC100 steel discs ( $d=15 \mathrm{~mm}, 3 \mathrm{~mm}$ thick). A detailed description of the sputtering system has been reported elsewhere. ${ }^{10}$ The chamber was pumped down to a base pressure under $2 \times 10^{-5} \mathrm{~Pa}$ before the depositions. The total pressure during the deposition was fixed to $0.4 \mathrm{~Pa}$ with the nitrogen partial pressure $\mathrm{P}_{\mathrm{N} 2}$ set at $0.1 \mathrm{~Pa}\left(\mathrm{P}_{\mathrm{Ar}}\right.$ is $\left.0.3 \mathrm{~Pa}\right)$. The typical composition of $\mathrm{XC100}$ steel is as follows: 0.95 to $1.05 \mathrm{wt}-\% \mathrm{C}, 0.5$ to $0.8 \mathrm{wt}-\% \mathrm{Mn}, 0.05 \mathrm{wt}-\% \mathrm{~S}$, $0 \cdot 25 \mathrm{wt}-\% \mathrm{Si}, 0 \cdot 035 \mathrm{wt}-\% \mathrm{P}$ and $\mathrm{S}$, with $\mathrm{Fe}$ as the balance. The average roughness $R_{\mathrm{a}}$ of XC100 steel substrates is $\sim 30 \mathrm{~nm}$. The distance between the confocal arranged targets and the substrate was $80 \mathrm{~mm}$. Before deposition, the substrates were situated under $\mathrm{Ar}^{+}$ions bombardment for $5 \mathrm{~min}$ at $-1000 \mathrm{~V}$ and at $10 \mu \mathrm{bar}$. During deposition, the substrate temperature was estimated around $150-350^{\circ} \mathrm{C}$. In this study, $\mathrm{Cr}(99.95$ at- $\%)$ and $\mathrm{V}$ $(99.98$ at $-\%$ ) targets were used to co-deposit the $\mathrm{Cr}-\mathrm{V}-\mathrm{N}$ films. Moreover, before deposition, the $\mathrm{Cr}$ and $\mathrm{V}$ targets were cleaned with an $\mathrm{Ar}^{+}$discharge for $5 \mathrm{~min}$ at $250 \mathrm{~W}$ $(-500 \mathrm{~V})$ and a working pressure of $0.4 \mathrm{~Pa}$. Before deposition of the nitride coatings, the substrates were coated with 230-250 nm thick $\mathrm{Cr}$ (or V) underlayers to improve adhesion. Coatings with different $\mathrm{Cr} / \mathrm{V}$ ratios were obtained by varying the power (the bias voltage) applied to the $\mathrm{Cr}$ and $\mathrm{V}$ targets from 0 to $650 \mathrm{~W}$ $(-900 \mathrm{~V})$. The deposition time was fixed at $90 \mathrm{~min}$, and the parameters of the deposited films are summarised in Table 1 . The thickness of the coatings was determined by

Table 1 Deposition conditions of the $\mathrm{Cr}-\mathrm{V}-\mathrm{N}$ thin films*

\begin{tabular}{|c|c|c|c|}
\hline \multicolumn{4}{|c|}{$\mathrm{CrN}$} \\
\hline \multicolumn{2}{|c|}{ A. power $(\mathrm{Cr}) / \mathrm{W}$} & \multicolumn{2}{|c|}{ Targets bias $(\mathrm{Cr})(-\mathrm{V})$} \\
\hline \multicolumn{2}{|c|}{$\begin{array}{l}650 \\
\text { Cr-V-N }\end{array}$} & \multicolumn{2}{|l|}{900} \\
\hline \multicolumn{2}{|c|}{ A. power/W } & \multicolumn{2}{|c|}{ Targets bias $(-\mathrm{V})$} \\
\hline $\mathrm{Cr}$ & $\mathrm{V}$ & $\mathrm{Cr}$ & v \\
\hline $\begin{array}{l}650 \\
650 \\
350 \\
\text { VN }\end{array}$ & $\begin{array}{l}260 \\
550 \\
550\end{array}$ & $\begin{array}{l}900 \\
900 \\
500\end{array}$ & $\begin{array}{l}500 \\
900 \\
900\end{array}$ \\
\hline $\begin{array}{l}\text { B. } \\
550\end{array}$ & & $\begin{array}{l}\text { Targ } \\
900\end{array}$ & $(-\mathrm{V})$ \\
\hline
\end{tabular}

*A. power Working pressure of $0.4 \mathrm{~Pa}, 20 \% \mathrm{~N}_{2}+80 \% \mathrm{Ar}$ gas mixture and deposition time of $90 \mathrm{~min}$. optical profilometry (VEECO, Wyko NT-1100). The structure was analysed by X-ray diffraction (XRD) using a SIEMENS D500, with a Co $K_{\alpha}$ radiation source $\left(30 \mathrm{kV}, 50 \mathrm{~mA}, \lambda_{\mathrm{Co}}=0 \cdot 178 \mathrm{~nm}\right)$. The average grain sise of the thin films was determined by Scherrer's method ${ }^{11}$

$$
D=\frac{0 \cdot 9 \lambda}{\beta \cos \theta}
$$

where 0.9 is the shape factor, $\lambda$ represents the $\mathrm{X}$-ray wavelength that was used for the measurement $\left(\lambda_{\mathrm{Co}}=0 \cdot 178 \mathrm{~nm}\right), \beta$ is the line width (full width half maximum) in radians and $\theta$ is the Bragg's angle. The position of the (111) diffraction peak was used to estimate the grain size. The surface morphology and the film structure were observed by a scanning electron microscopy HR-SEM system, which was equipped with an energy dispersive X-ray spectrometer (EDS) to determine the chemical composition. The X-ray photoelectron spectroscopy (XPS) analysis was performed to verify the chemical composition. The film surface roughness was measured by atomic force microscopy (AFM; nanoscope V). The hardness and Young's modulus of the coatings were investigated by nanoindentation (MTS-XP) in continuous stiffness mode, where the tip oscillates with a frequency of $45 \mathrm{~Hz}$ and amplitude of $2 \mathrm{~nm}$. A diamond Berkovich indenter with a tip radius of $\sim 200 \mathrm{~nm}$ was used in the experiments with a maximum load of $10 \mathrm{mN}$. The loading and unloading phases of the indentations were carried out under load control at a nominal rate of $0.05 \mathrm{mN} \mathrm{s}^{-1}$. The reported values were determined from the average of five indentations and were evaluated at a depth of $5 \%$ of the total film thickness in order to avoid influences from the steel substrate and/or the surface roughness. The hardness and elastic modulus of the coatings were calculated using the Oliver and Pharr method. ${ }^{6}$ The compressive residual stresses $\sigma$ of the films were calculated with Stoney's formula ${ }^{12}$

$$
\sigma= \pm \frac{E_{\mathrm{s}}}{6\left(1-v_{\mathrm{s}}\right)} \times \frac{e_{\mathrm{s}}^{2}}{e_{\mathrm{f}}}\left(\frac{1}{R}-\frac{1}{R_{0}}\right)
$$

where $\sigma$ is the residual stress in the thin film, $E_{\mathrm{s}}$ and $v_{\mathrm{s}}$ are Young's modulus (195 GPa) and Poisson's ratio $(0 \cdot 29)$ of the substrate, $e_{\mathrm{f}}$ and $e_{\mathrm{s}}$ indicate the film and substrate thicknesses respectively, $R$ is the curvature radius of the sample after deposition and $R_{0}$ is the curvature radius before deposition. Pin on disc and oscillating (TRIBO tester) wear tests were carried out to characterise the tribological performance of the coatings. The counterparts were 100Cr6 steel balls, $6 \mathrm{~mm}$ in diameter. The applied load was increased progressively from 0 to $5 \mathrm{~N}$ within the sliding speed of $0.5 \mathrm{~m} \mathrm{~s}^{-1}$. The maximum sliding distance was $600 \mathrm{~mm}$, and the wear track diameter was $2 \mathrm{~mm}$ under a test temperature of $21 \cdot 5^{\circ} \mathrm{C}$ and a relative humidity of $33 \cdot 2 \%$. Each test lasted $\sim 10$ min. During the measurement, the experiment parameters such as transverse force and acoustic emission are recorded for subsequent data analysis. The coating/substrate interfacial adhesion was investigated the use of scratch tests (Scratch Tester Millenium 200). This apparatus was equipped with an optical microscope and a Rockwell diamond indenter (with a tip radius and a conical angle of $200 \mu \mathrm{m}$ and $120^{\circ}$ respectively). In addition, it can apply a maximum load 
of $100 \pm 0 \cdot 05 \mathrm{~N}$. The stripping speed and the strip length were $10 \mathrm{~mm} \mathrm{~min}^{-1}$ and $10 \mathrm{~mm}$ respectively. After the tests, the attached optical microscope observed the tracks for the determination of critical loads.

\section{Results and discussion}

\section{Microstructure and chemical composition}

Chemical compositions of the $\mathrm{Cr}-\mathrm{V}-\mathrm{N}$ thin films are presented in Table 2. The $\mathrm{CrN}$ coating has an $\mathrm{N} / \mathrm{Cr}$ atomic ratio $\sim 0.96$; this is the characteristic of the cubic CrN phase. ${ }^{12}$ Figure 1 shows the XRD patterns of the $\mathrm{CrN}, \mathrm{VN}$ and $\mathrm{Cr}-\mathrm{V}-\mathrm{N}$ films, which are deposited on $\mathrm{XC100}$ steel substrates. The $\mathrm{Cr}-\mathrm{N}$ coating exhibits an $\mathrm{NaCl}$ cubic structure with a $\mathrm{CrN}$ (111) diffraction peak at $44 \cdot 29^{\circ}$ and ${ }^{2} \mathrm{Cr}_{2} \mathrm{~N}$ (111) diffraction peak at $50 \cdot 37^{\circ}$, which are similar to the observations in previous studies. ${ }^{13,14}$ The (111) diffraction peak of the $\mathrm{CrN}$

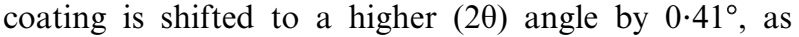
compared to the JCPDS (00-011-0065) reference file; this is probably related to a compressive residual stress $(-1.980 \mathrm{GPa})$, as it is shown in Table 2, which was possibly generated by the ion bombardment from the high applied power $(650 \mathrm{~W})$ in the plasma. Figure 2 shows the XPS spectra of $\mathrm{Cr} 2 \mathrm{p}, \mathrm{N} 1 \mathrm{~s}$ and $\mathrm{V} 2 \mathrm{p}$ for $\mathrm{Cr}-\mathrm{V}-\mathrm{N}$ films in each one with different $\mathrm{Cr}$ to $\mathrm{V}$ ratios. The XPS core level spectrum of $\mathrm{N}$ 1s shown in Fig. 2 exhibits almost a symmetric shape. For a pure $\mathrm{CrN}$ film, the $\mathrm{Cr} 2 \mathrm{p}_{3 / 2}$ binding energy is obtained at $574.40 \mathrm{eV}$. According to Conde et al., the peak corresponds to a $\mathrm{CrN}$ film for $\mathrm{Cr}-\mathrm{N}$ bonds. ${ }^{15}$ The $\mathrm{N}$ 1s spectrum shows a single wide peak at $397 \cdot 1 \mathrm{eV}$. In addition, according to Barshilia et al., ${ }^{16}$ this value probably corresponds to nitrogen in the $\mathrm{CrN}(397.0 \mathrm{eV})$, which gives a supplementary evidence supporting $\mathrm{N}$ element bonded to $\mathrm{Cr}$ during the coating deposition. The above results are in an excellent consistent with the XRD analysis.

Figure 3 shows the cross-sectional of $\mathrm{Cr}-\mathrm{V}-\mathrm{N}$ coatings, and Fig. 4 shows their top view SEM images. The $\mathrm{CrN}$ coating presents a compact columnar structure that appears to extend through the thickness of the coating. The average grain size of the $\mathrm{CrN}$ coating was estimated by the Scherrer formula using the (111) reflection, ${ }^{6}$ which was $72 \mathrm{~nm}$ (Figs. $3 a$ and $4 a$ ). Wang et $a l^{13}$ obtained the same structure on the $\mathrm{CrN}$ coatings prepared by unbalanced magnetron sputtering, however with a preferential (200) orientation. Because of the presence of both $\mathrm{CrN}$ and $\mathrm{Cr}_{2} \mathrm{~N}$ phases in the $\mathrm{CrN}$ structure, as shown in the XRD pattern (Fig. 1), it is difficult to glean more quantitative information from the structural zone of this coating, This structure probably appears to be between the Ic zone and the transitional (T) zone according to Mahieu's model, ${ }^{17}$ because the top of the columns are relatively flat, and the layer is also well crystallised. Ortmann et al. ${ }^{18}$ showed a similar structure for $\mathrm{CrN}$ films deposited by plasma activated physical vapour deposition. The $\mathrm{CrN}$ coating thickness and RMS roughness (according to AFM observations) were $1.26 \mu \mathrm{m}$ and $23 \cdot 3 \mathrm{~nm}$ respectively. Table 2 shows the influence of the vanadium content on the overall chemical composition of the $\mathrm{Cr}-\mathrm{V}-\mathrm{N}$ coatings. The $\mathrm{V}$ content varies from 10 to 38 at $-\%$ (Table 2). As expected, the $\mathrm{Cr}$ content and the $\mathrm{Cr}$ applied power are decreased, whereas the $\mathrm{V}$ content increases with increased within $\mathrm{V}$ applied power. The nitrogen content

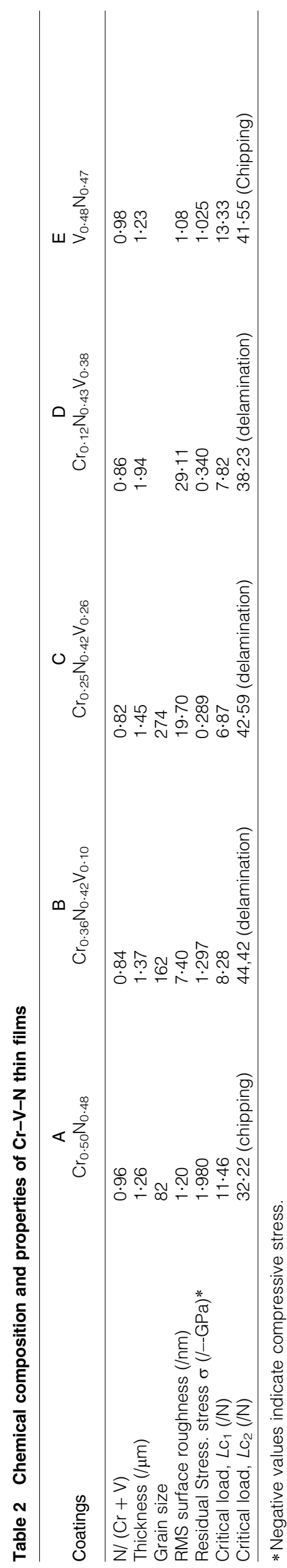




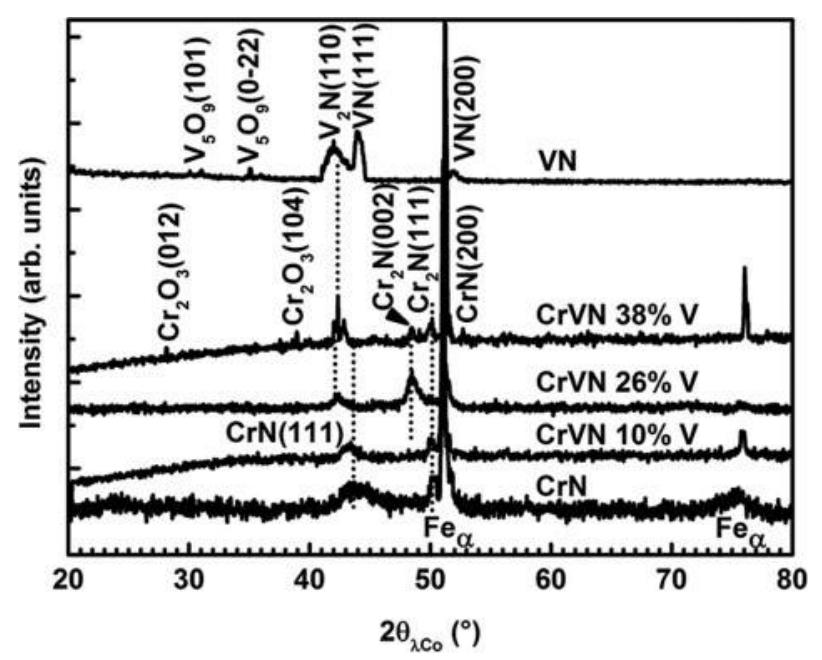

1 X-ray diffraction patterns of $\mathrm{Cr}-\mathrm{V}-\mathrm{N}$ thin films

of the coatings is relatively between 42 and 43 at- $\%$. The diffraction patterns of the $\mathrm{Cr}-\mathrm{V}-\mathrm{N}$ layers (Fig. 1) indicate planar spacing, which is typical of the $\mathrm{NaCl}$ cubic structure with an overlap of both (111) and (200) orientations of $\mathrm{CrN}$ and VN. At 26 at $-\%$ of $\mathrm{V}$, a broad $\mathrm{Cr}_{2} \mathrm{~N}$ (002), a minor $\mathrm{Cr}_{2} \mathrm{~N}$ (111) and also minor $\mathrm{V}_{2} \mathrm{~N}$ (110) diffraction peaks are also detected. In addition, the $\mathrm{Cr}_{2} \mathrm{O}_{3}$ is detected in the $\mathrm{Cr}_{0.12} \mathrm{~V}_{0.38} \mathrm{~N}_{0.43}$ coating at 38 at$\%$ of $\mathrm{V}$. Within the $\mathrm{Cr}-\mathrm{V}-\mathrm{N}$ coatings, peak positions of $\mathrm{Cr}-\mathrm{V}-\mathrm{N}$ films are at lower angle than that of $\mathrm{VN}$ and $\mathrm{CrN}$. This may suggests that $\mathrm{Cr}-\mathrm{V}-\mathrm{N}$ films consist of solid solution between $\mathrm{CrN}$ and, VN. On the other hand, the $\mathrm{CrN}$ (111) peak intensity gradually decreases with increasing $\mathrm{V}$ content and $\mathrm{CrN}$ and $\mathrm{VN}$ disappears entirely from the XRD pattern of the 38 at $-\% \mathrm{~V}$ coating. This may be due to the presence of an in plane compressive stress ${ }^{19}$ and/or the substitution of $\mathrm{V}$ atoms into some $\mathrm{Cr}$ lattice sites. Unlike, the $\mathrm{Cr}_{2} \mathrm{~N}(002)$ and (111), $\mathrm{VN}(111)$, and $\mathrm{V}_{2} \mathrm{~N}$ (110) orientations gradually emerged in the XRD patterns; this can be related to the increase in the applied power of the $\mathrm{V}$ target. Similar results were observed for (V, Ti) $\mathrm{N}$ films, ${ }^{20}$ where TiN diffraction peaks are not detected, because $\mathrm{VN}$ diffraction peaks are significantly stronger. This suggests that $\mathrm{Cr}-\mathrm{V}-\mathrm{N}$ films is composed of a solid solution of $\mathrm{Cr}$ and $\mathrm{V}$, i.e. vanadium atoms substituted into chromium lattice sites. Previous studies have shown similar results for vanadium ions implanted into $\mathrm{CrN}$ films by metal vapour vacuum arc implantation, ${ }^{13}$ and for $\mathrm{Cr}-\mathrm{V}-\mathrm{N}$ films deposited by cathodic arc ion plating method. ${ }^{7}$ For the $\mathrm{Cr}-\mathrm{V}-\mathrm{N}$ films, the XPS analysis yields binding energies of $\mathrm{Cr} 2 \mathrm{p}_{3 / 2}$ and $\mathrm{N} 1 \mathrm{~s}$ are $(397.4$ and $574.6 \mathrm{eV})$ at $10 \mathrm{at}-\% \mathrm{~V}$ and $(397 \cdot 6$ and $574.8 \mathrm{eV}$ ) at 26 and 38 at- $\% \mathrm{~V}$. In general, Cr $2 \mathrm{p}_{3 / 2}$ and $\mathrm{N}$ 1s shifted to high binding energies with the increase in the $\mathrm{V}$ content than that of $\mathrm{CrN}$ reference. The components observed would relate more to metallic $\mathrm{Cr}$, which could be related to $\mathrm{Cr}_{2} \mathrm{~N}$, or, they correspond to $\mathrm{Cr}-\mathrm{N}-\mathrm{O}$ bonds, with some trace of $\mathrm{Cr}_{2} \mathrm{O}_{3}$ formed by insertion of oxygen. ${ }^{15}$

For the V 2p XPS peaks, between 10 and 26 at- $\%$ V, the $\mathrm{V}$ spectra did not give any information because of the feeble $\mathrm{V}$ concentration in the films. At 38 at $-\%$ of $\mathrm{V}$
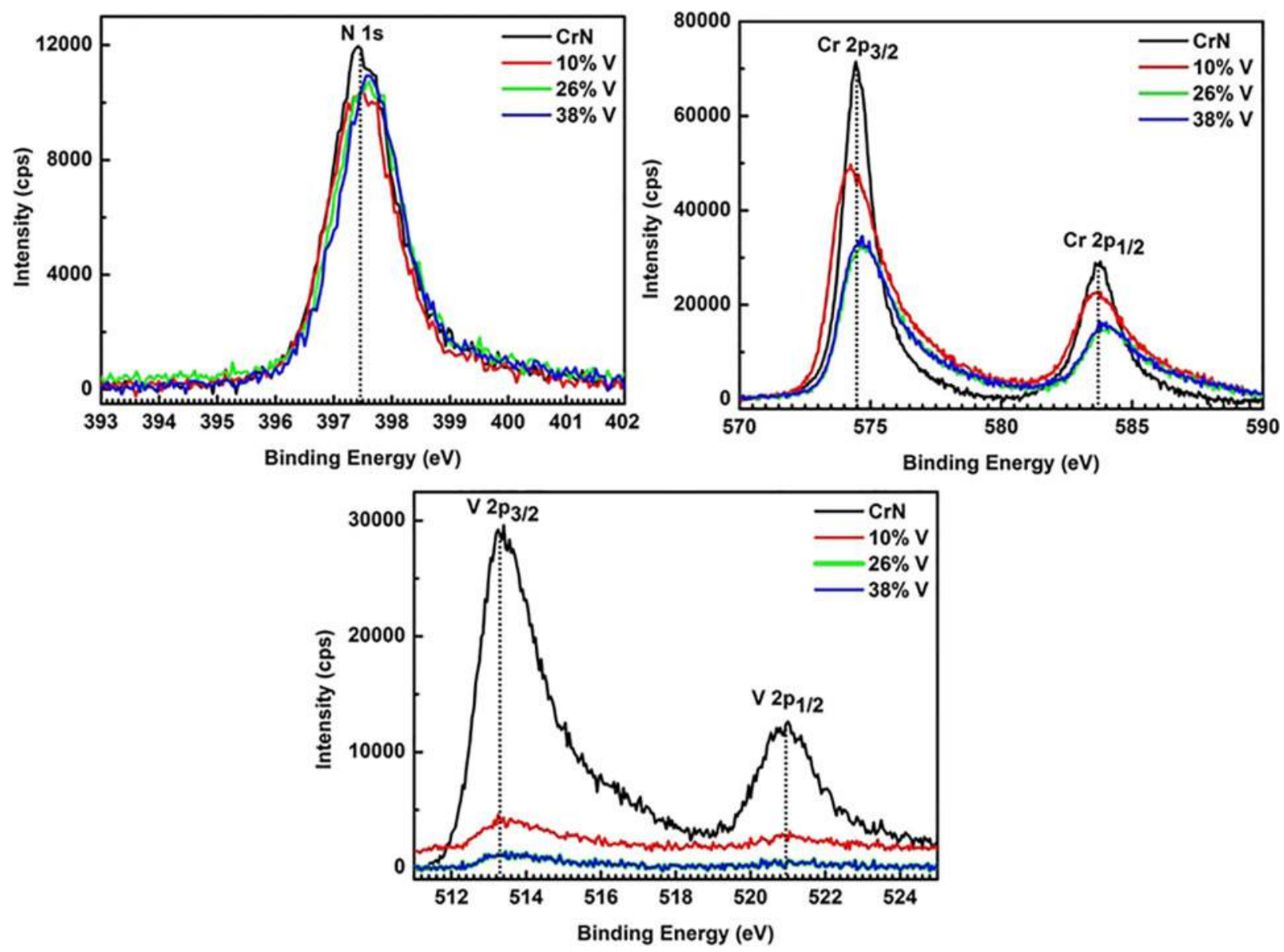

2 X-ray photoelectron spectroscopy spectra for $\mathrm{Cr}-\mathrm{V}-\mathrm{N}$ thin films 

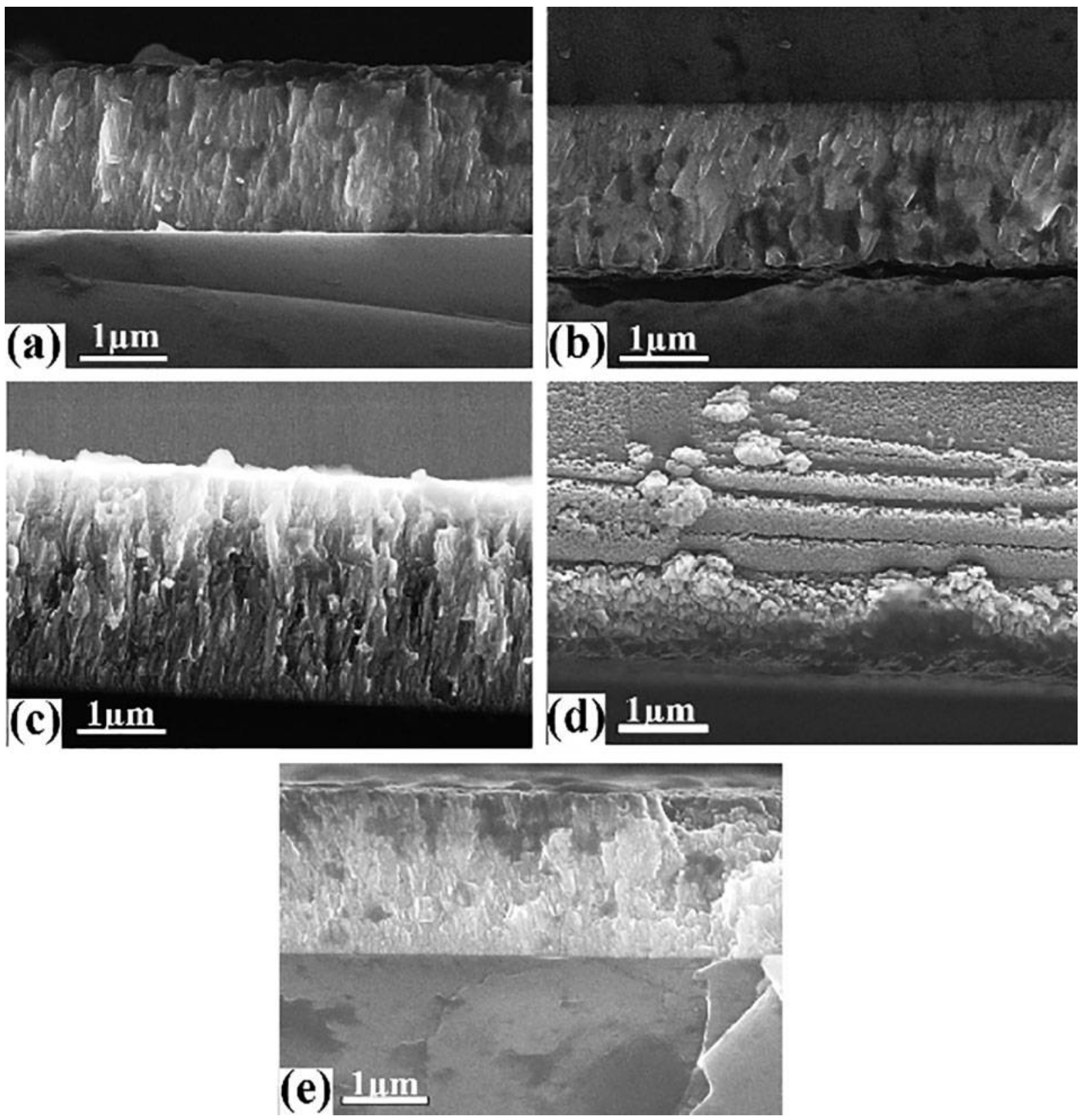

3 Cross-sectional SEM images of $a \mathrm{CrN}, \mathrm{Cr}-\mathrm{V}-\mathrm{N}$ at $b 10$ at-\% V, $c 26$ at-\% V, $d 38$ at-\% V and $e$ VN thin films

content, the peak takes $513.42 \mathrm{eV}$ with a small intensity. Compared to the one that is measured by Yang et al., the peak positions correspond to the $\mathrm{VN}_{\mathrm{x}}$ phase. ${ }^{21} \mathrm{At}$ 10 at $\% \mathrm{~V}$, a dense and a columnar structure with a pyramid-like surface (size $\sim 93 \mathrm{~nm}$ ) is seen in Figs. $3 b$ and $4 b$. At 26 at $-\% \mathrm{~V}$, this microstructure very clearly coalesced to large grains (size $\sim 192 \mathrm{~nm}$ ) as in Fig. $4 c$. For the film with 38 at $-\%$ of $\mathrm{V}$, the surface shows more pronounced facets with even larger grains $(\sim 245 \mathrm{~nm})$ than that at 26 at $-\% \mathrm{~V}$ or at 10 at $-\% \mathrm{~V}$ (Fig. $4 d$ ). In addition, this structure was observed for $\mathrm{Ti}-\mathrm{V}-\mathrm{N}$ and $\mathrm{Ti}-\mathrm{Al}-\mathrm{N}$ films deposited by reactive magnetron sputtering. ${ }^{22}$

The change in the $\mathrm{CrN}$ film structure by adding the vanadium content is due to the change in the growth mechanism for the $\mathrm{Cr}-\mathrm{V}-\mathrm{N}$ coatings. Actually, for a low $\mathrm{V}$ power supply (or bias voltage) $(260 \mathrm{~W},-500 \mathrm{~V})$, it is expected there would be significantly less effects from ion bombardment than at a higher $\mathrm{V}$ power supply
$(550 \mathrm{~W},-900 \mathrm{~V})$. Indeed, at low $\mathrm{V}$ power supply (10 at- $\%$ $\mathrm{V})$, the film appears dense, with less defined columnar growth than those with high $\mathrm{V}$ content. Because, during the deposition, an energetic ion flux resulting from the sputtering effect and the heat of effective momentum transfer attacks the film surface and hence encourages diffusion. Thus, weakly deposited particles were removed and new precipitated compounds are formed, changing the surface morphological surface. Relating to Mahieu's model, the $\mathrm{Cr}-\mathrm{V}-\mathrm{N}$ films are clearly within the transition between zone $\mathrm{T}$ and zone 2 between 10 and 26 at- $\% \mathrm{~V}$ content. However, the high $\mathrm{V}$ content coatings appear to be near the transition to zone $2 .{ }^{17}$ The influence of $\mathrm{V}$ content on $\mathrm{Cr}-\mathrm{V}-\mathrm{N}$ coating morphology is also evaluated by measuring the roughness and the film thickness. As a function of $\mathrm{V}$ content, optical profilometry and AFM analyses yield coating thicknesses (RMS roughness) of $1.37 \mu \mathrm{m}(29.60 \mathrm{~nm}), 1.45 \mu \mathrm{m}(56.39 \mathrm{~nm})$ and $1.94 \mu \mathrm{m}$ $(86 \cdot 17 \mathrm{~nm})$ for 10,26 and 38 at $-\% \mathrm{~V}$ (Table 2 ) respectively. 

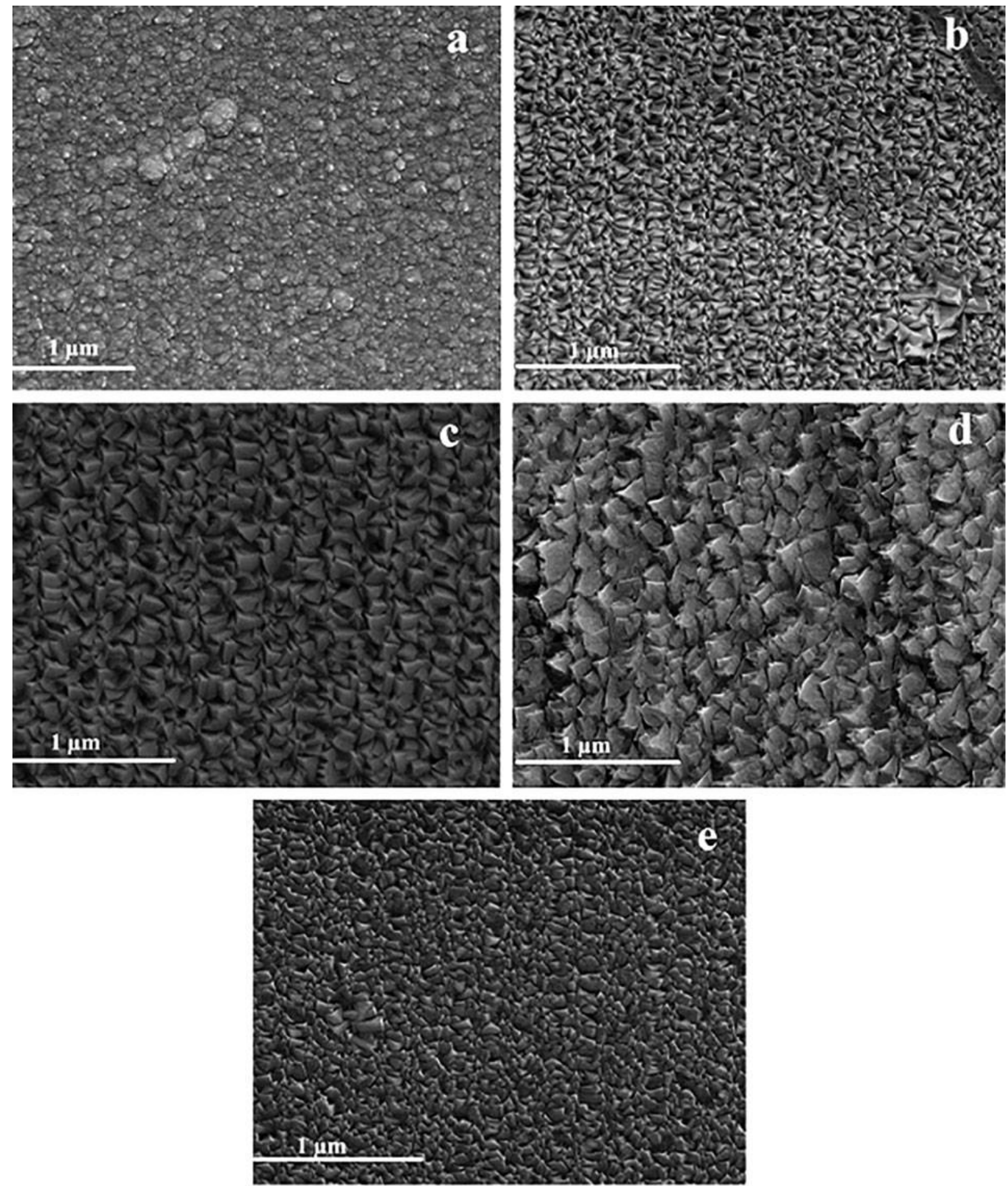

\section{Surface morphologies (SEM) of $a \mathrm{CrN}, \mathrm{Cr}-\mathrm{V}-\mathrm{N}$ at $b 10$ at- $\% \mathrm{~V}, c 26$ at- $\% \mathrm{~V}, d 38$ at-\% V and $e$ VN thin films}

This is possibly to a meager increase in the film thickness despite a high applied power due to a lower deposition rate of vanadium than chromium, and residual stresses are generated by the higher ion energy bombardment. This increase may be explained also with the atomic shadowing effect theory. Namely, during the film growth some of the crystalline orientations can be more favoured than the others, as the increase in the grain size leads to an increase in the surface roughness. This is similar to earlier observations of the $\mathrm{Cr}-\mathrm{N}$ system deposited by magnetron sputtering technique. ${ }^{23}$ The VN layer presents an N/V atomic ratio $\sim 0.98$ with a nitrogen concentration of 48 at- $\%$, indicating that the film is almost stoichiometric
(Table 2). The XRD pattern of the VN coating is shown in Fig. 1. Two diffraction peaks VN (111) and (200) at 43.96 and $51 \cdot 83^{\circ}$ respectively referred to JCPDS $(00-073-0528)$ and a minor $\mathrm{V}_{2} \mathrm{~N}(110)$ at $43 \cdot 03^{\circ} \mathrm{JCPDS}(00-032-1413)$ are detected; similar peaks were also detected in previous studies. ${ }^{24}$ No apparent peak shift is observed for this film. Moreover, minor $\mathrm{V}_{5} \mathrm{O}_{9}(101)$ and (0-22) diffraction peaks are located at 30.58 and $35 \cdot 50^{\circ}$ JCPDS (00-018-1450) respectively. From the XPS analysis, a good correlation between the stoichiometry of the film and the binding energy positions of $\mathrm{V}$ and $\mathrm{N} 1 \mathrm{~s}$ peaks $(513.40$ and $397 \cdot 3 \mathrm{eV}$ ) has been observed, which corresponded to a VN stoichiometry. The cross-section of VN coating presented 
a compact and columnar structure with a faceted surface $($ size $\sim 90 \mathrm{~nm})($ Fig. $3 e$ ). The VN surface did not show any discontinuity or defect, which refers to zone T in Mahieu's model. ${ }^{17}$ In addition to this, the VN coating has a smaller thickness and lower RMS roughness $(1 \cdot 23$ and $27 \cdot 31 \mathrm{~nm})$ than $\mathrm{CrN}$ (Table 2). Negligible oxygen concentration is detected in the pure $\mathrm{CrN}$ film; however, non-negligible amounts are detected in all $\mathrm{Cr}-\mathrm{V}-\mathrm{N}$ and $\mathrm{VN}$ films. Both $\mathrm{Cr}$ and $\mathrm{V}$ show strong affinities to oxygen. In addition, the mixing of these elements during deposition can form a strong base for the formation of oxides. ${ }^{25}$ The oxygen contamination may be the result of a leak during coating deposition.

\section{Mechanical properties}

The hardness $H$ and Young's modulus $E$ of the studied coatings as a function of $\mathrm{V}$ content in the $\mathrm{Cr}-\mathrm{V}-\mathrm{N}$ layers are given in Fig. 5. The residual stress $\sigma$ of all coatings is compressive and appears to follow the same trend as the coatings' hardness and Young's modulus. The CrN film presents the higher hardness and Young's modulus $(H=19.53 \mathrm{GPa}, E=287 \mathrm{GPa})$. This may be due to its high stress level (Table 2) and dense structure $^{20}$ as observed in Fig. 3. Increasing the $\mathrm{V}$ content in the $\mathrm{Cr}-$ $\mathrm{V}-\mathrm{N}$ system causes a drop in both hardness and Young's modulus. Nanoindentation tests yield hardness and Young's modulus of 11.27 and $239 \mathrm{GPa}, 8.23$ and $254 \mathrm{GPa}$ and $5 \cdot 27$ and $223 \cdot 39 \mathrm{GPa}$ for coatings with 10 , 26 and 38 at- $\%$ of $\mathrm{V}$ respectively (Fig. 5). For almost $\mathrm{Cr}-\mathrm{V}-\mathrm{N}$ coatings, the mechanical properties are lower than the XC100 substrate $(H=10 \cdot 32 \mathrm{GPa}$, $E=226 \cdot 13 \mathrm{GPa}$ ), while there are several possible reasons for the observed decline in mechanical properties. Jiang et al. $^{26}$ explained the decline via the surface roughness effect. Indeed, the higher surface roughness with larger grains in the high $\mathrm{V}$ films could alter the contact between the indenter tip and the surface of the sample. This would greatly affect the accuracy of the nanoindentation measurement in our case. Another possible explanation is that an actual decrease in the mechanical properties of the film is induced by the film growth mechanism. The typical growth mechanism for $\mathrm{Cr}-\mathrm{V}-\mathrm{N}$ films tends to form rough columnar structures, which are clearly observed in the surface micrographs of Fig. 4. This type of growth may introduce more voids in the structure. Porous ceramics compounds such as chromium carbides coatings have shown significantly a reduced hardnesses compared to their non-porous

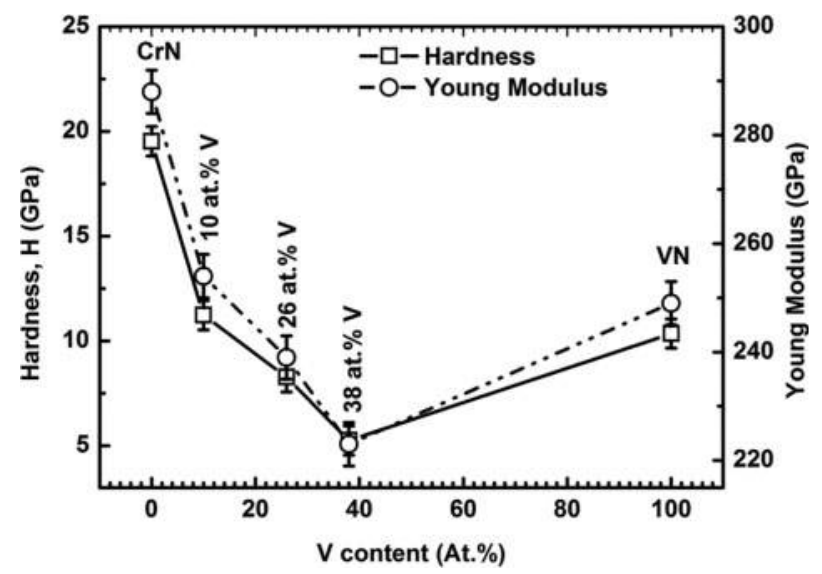

5 Hardness and Young's modulus of Cr-V-N thin films counterparts. ${ }^{27}$ Moreover, Bouzakis et al. ${ }^{28}$ explained the decline in the mechanical properties by the relaxation of residual stress with increasing film thickness, and the development of dominant $\mathrm{V}_{2} \mathrm{~N}$ and $\mathrm{Cr}_{2} \mathrm{~N}$ phases, which are less dense as compared to the $\mathrm{CrN}$ phase. Similar results are reported for $\mathrm{Cr}-\mathrm{V}-\mathrm{N}^{7}$ and $\mathrm{Ti}-\mathrm{V}-\mathrm{N}^{9}$ films obtained with high $\mathrm{V}$ content. Moreover, it is well known that the (111) orientation is the hardest for face centred cubic nitride films. ${ }^{29}$ As well as the increase in $\mathrm{V}$ content, there is a decrease in the $\mathrm{CrN}$ (111) intensity that corresponds to the observed decrease in hardness. An additional reason for the mechanical properties decline is the high oxygen contamination of $\mathrm{Cr}-\mathrm{V}-\mathrm{N}$ coatings (Table 2). The oxygen ( 6 to 8 at- $\%$ ) is typically bonded, forming oxides that may affect the coating mechanical properties in addition to this similar trends was observed on sputtered $\mathrm{Cr}-\mathrm{Zr}-\mathrm{N}^{30}$ and $\mathrm{W}-\mathrm{A} 1-\mathrm{N}$ films. ${ }^{31}$ In our work, the low hardness values for $\mathrm{Cr}-\mathrm{V}-\mathrm{N}$ films may be due to the decrease in $\mathrm{CrN}$ (111) orientation, relaxation in the compressive stress, increased surface roughness and oxygen contamination. The pure $\mathrm{VN}$ film showed a slight increase in hardness and Young's modulus to $10 \cdot 35$ and $249 \mathrm{GPa}$. The average value of the Young's modulus is lower than that of polycrystalline vanadium nitride, which is typically $342 \mathrm{GPa}$. ${ }^{9}$ The slight increase in the mechanical properties of the $\mathrm{VN}$ layer in comparison to the $\mathrm{Cr}-\mathrm{V}-\mathrm{N}$ ones is in agreement with the microstructure change (Fig. 4) because the shadowing effect is reduced and the voids in the microstructure are filled due to the surface diffusion of adatoms, which causes an improvement in mechanical properties. ${ }^{32}$ In addition, this small rise in hardness can partly explained by the decrease in both grain size and RMS roughness. Unlike, the mechanical properties of the films are still poor in comparison to the CrN film. Latella et al. ${ }^{9}$ found similar results when working within the TiVN system. Moreover, it may be useful to remember that the VN coating does suffer from significant oxygen contamination $(4-5 \%)$, which will affect adversely the mechanical properties (7-8 at. \%).

\section{Tribological properties \\ Friction coefficient}

The evolution of the friction coefficient $\mu$ was determined by pin on disc tests as a function of the $\mathrm{V}$ and $\mathrm{Cr}$ contents (Fig. 6). Each test lasted 10 min under a 5 N load; a 100Cr6

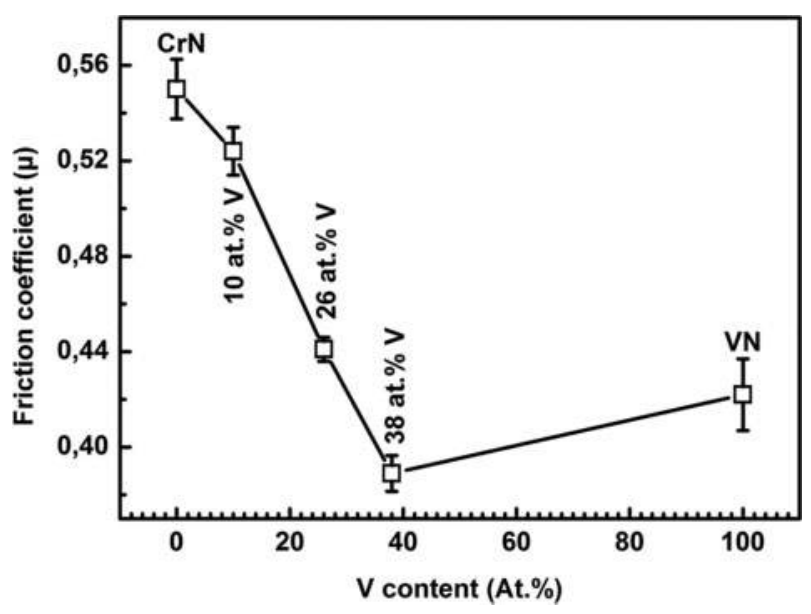

6 Friction coefficient of $\mathrm{Cr}-\mathrm{V}-\mathrm{N}$ thin films 

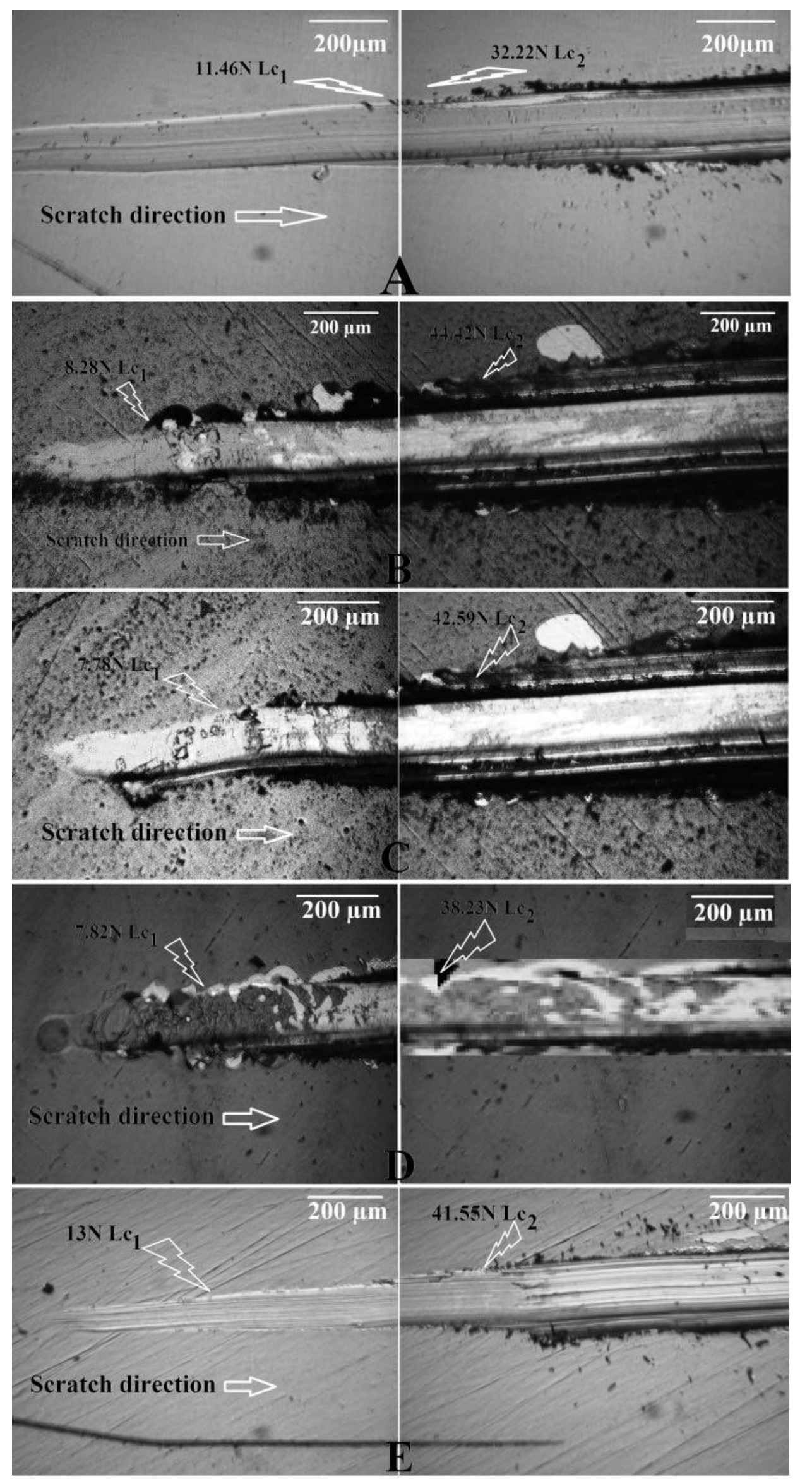

7 Micrographs of scratch tracks of $a \mathrm{CrN}, \mathrm{Cr}-\mathrm{V}-\mathrm{N}$ at $b 10$ at-\% V, $c 26$ at- $\% \mathrm{~V}, d 38$ at-\% V and $e$ VN thin films 
steel ball was the counterpart. The average friction coefficient of the $\mathrm{CrN}$ film is $0 \cdot 55$, indicating that the $\mathrm{CrN}$ has a good abrasive resistance, as reported by Zhao et al. ${ }^{33}$ However, the friction coefficient is slightly highly comparable to that exhibited by $\mathrm{CrN}$ films deposited on AISI 304 stainless steel sample by a PVD Alcatel SCM 450 sputtering system $(0 \cdot 50){ }^{34}$ This difference is due to friction forces that are acting at the interface between the $\mathrm{CrN}$ coating and the substrate. In addition, the magnitude of those forces is related to the surface properties of the two materials. From $\mathrm{Cr}-\mathrm{V}-\mathrm{N}$ coatings, a clear trend was observed between the mechanical properties (hardness and Young's modulus) and the friction coefficient. In addition, similar results were obtained for ternary $\mathrm{Ti}-\mathrm{V}-\mathrm{N}$ coatings by Latella et al., ${ }^{9}$ who explained this correlation by the dynamical behaviour of dislocations with the vanadium substitution of titanium atoms in the film structure. However, Sarakinos et al. ${ }^{35}$ explained this result by the change in the micro/nanostructure of carbon based compounds, which possessed similar tribological parameters. Compared with the friction coefficient of $\mathrm{CrN}$ coating $(0 \cdot 55)$, the $\mathrm{Cr}-\mathrm{V}-\mathrm{N}$ coatings have a slightly lower friction coefficient of $\sim 0.39$. According to Yuexiu et al. ${ }^{4}$ this is attributed to the contamination of the $\mathrm{Cr}-\mathrm{V}-\mathrm{N}$ coating by oxygen, and formation of oxides. These oxides act as a lubricant between two counterparts. ${ }^{4}$ In addition, the presence of these composes in the film contributes to the low coefficient of friction. For VN film, the friction coefficient is 0.42 against $100 \mathrm{Cr} 6$ ball, which is in good agreement with the measurements of VN coatings, which is deposited by unbalanced magnetron sputtering by Fateh et al. ${ }^{36}$ However, it is significantly higher than VN films $(0 \cdot 33)$ deposited by DC magnetron sputtering. The VN coating exhibited a lower friction coefficient than $\mathrm{CrN}$ coating (Fig. 6 ), while the lower surface roughness of the VN coating is contributing to the lower friction coefficient. In similar results of VN films by Yuexiu et al. ${ }^{4}$ who explained the low friction coefficient of $\mathrm{VN}$ film by the presence of vanadium oxides at its surface. As with the $\mathrm{Cr}-\mathrm{V}-\mathrm{N}$ coating, also the presence of oxides within the film may play a role in the reduced coefficient of friction.

\section{Scratch tests}

Scratch tests were carried out to investigate the adhesion between the coatings and the XC100 steel substrates. Two critical loads were defined: the cohesive failure critical load $L \mathrm{c}_{1}$, corresponding to the beginning of cracking in the coatings, and the adhesion failure critical load $L c_{2}$, corresponding to the chipping or the delamination of coatings. ${ }^{35} L c_{1}$ and $L c_{2}$ versus the $V$ content are presented in Table 2. The scratch tracks of the coatings deposited at various $\mathrm{V}$ content were observed by optical microscopy as shown in Fig. 7. It is obvious in (Table 2) that the critical loads followed a similar trend as the friction coefficient, but the inverse tendency to the RMS roughness lower RMS roughness values resulted in higher critical loads. For the $\mathrm{CrN}$ coating, cohesive failure occurs at $\sim 11.46$ $\mathrm{N}$. The failure mechanism appears to be conformal cracking in the scratch track (Fig. 7a); these kinds of cracks are often associated with a hard coating $(\mathrm{CrN})$ coupled to a soft substrate (XC100). ${ }^{36}$ The chipping at the edge of the scratch track appears to be the initial stage for the adhesive failure of chromium nitride coating. The adhesive failure critical load $L c_{2}$ has a medium value of $32 \cdot 2 \mathrm{~N}$. However, this is lower as compared with the adhesion properties of $\mathrm{CrN}$ deposited by an ion plating PVD process onto X37CrMoV5-1 steel, ${ }^{37}$ which can be attributed to the presence of a high residual stress and a soft substrate. For the $\mathrm{Cr}-\mathrm{V}-\mathrm{N}$ coatings, the cohesive failures are significantly lower $(6 \cdot 9-8 \cdot 3 \mathrm{~N})$. However, adhesive failure occurred at higher critical loads, ranging from $44.4 \mathrm{~N}$ for 10 at $-\% \mathrm{~V}$ and then decreased slightly to $38 \cdot 2 \mathrm{~N}$ with the 38 at $-\% \mathrm{~V}$ coating. Thus, it appears that the addition of $\mathrm{V}$ to the $\mathrm{CrN}$ system has improved the adhesion of the layers. This may be explained by a reduction in the coatings' residual stress with the addition of $\mathrm{V}$ to the $\mathrm{Cr}-\mathrm{V}-\mathrm{N}$ system. In addition, the $\mathrm{Lc}_{2}$ values are inversely proportional to the residual stress in the case of $\mathrm{Cr}-\mathrm{Al}-\mathrm{N}$ films. ${ }^{38}$ Moreover, a different failure mechanism can be seen during the scratch testing of $\mathrm{Cr}-\mathrm{V}-\mathrm{N}$ coatings (Fig. 7). Similar to $\mathrm{CrN}$ coatings, the initial chipping/spallation occurs at the edge of the scratch track. However, with the $\mathrm{Cr}-\mathrm{V}-\mathrm{N}$ coatings, this behaviour extends past the edge of the coating onto the surface of the sample. In addition, this coating failure and removal appear more complete as several areas of the steel substrate were exposed. In addition, there is significantly more debris along the edge of the track in the initial failure $\left(L c_{1}<10 \mathrm{~N}\right)$, while a complete failure of the $\mathrm{Cr}-\mathrm{V}-\mathrm{N}$ coatings occurred at higher critical loads, and this may be due to their weak structure cohesion. Moreover, the addition of $\mathrm{V}$ decreases the friction coefficient, which can be an indicator of the coatings resistance to abrasion, i.e. lower coefficients of friction correlate with low critical loads for cohesive failure.

The VN coating (Table 2) has a significantly better $L \mathrm{c}_{1}$ (up to $13 \cdot 3 \mathrm{~N}$ ) when it is compared to the $\mathrm{Cr}-\mathrm{V}-\mathrm{N}$ coatings. Moreover, the critical load of adhesive failure was on the same order of magnitude $(41 \cdot 5 \mathrm{~N})$. In both cases (cohesive and adhesive failure), this is an improvement over the $\mathrm{CrN}$ coating. Yoshida et al. ${ }^{39}$ showed that for very soft coatings (hardness is on the order of $5 \mathrm{GPa}$ ), the films could resist plastic deformation. Nevertheless, when the coatings failed, there was interfacial spallation along the scratch track borders (Fig. 7e) and the VN coating flaked off the edge of the scratch track as well as the stylus passed by. These dramatic failures may originate from the coating's small thickness, and the differences in the mechanical properties between the coating and substrate.

\section{Conclusion}

$\mathrm{Cr}-\mathrm{V}-\mathrm{N}$ coatings were deposited onto $\mathrm{Si}$ and $\mathrm{XC100}$ steel substrates by RF dual magnetron sputtering. The structure, morphology, mechanical and tribological properties of the coatings were characterised. The results permit us to sum up as follows.

1. Both the pure $\mathrm{CrN}$ and $\mathrm{VN}$ films are well crystallised. The $\mathrm{CrN}$ coating is very dense and presents good mechanical and tribological properties.

2. From the XRD and EDS analyses, the $\mathrm{Cr}-\mathrm{V}-\mathrm{N}$ coatings appear to be composed of a solid solution, with vanadium substitution at chromium sites and exhibit a faceted grain structure with pyramid-like forms.

3. The mechanical and tribological properties of the $\mathrm{Cr}-\mathrm{V}-\mathrm{N}$ coatings were lower than that either the $\mathrm{CrN}$ or $\mathrm{VN}$ binary coatings are excepted in terms of COF. This may be due to the rough morphological surface and/or oxygen contamination. 
4. In this study, the addition of vanadium did not improve the mechanical and tribological properties of the $\mathrm{Cr}-\mathrm{N}$ system.

\section{Acknowledgements}

The authors would like to thank Mr Gildas Guillemot for the mechanical and tribological measurements carried out at Arts et Metiers ParisTech of Lille and Mr IMHOFF for the SEM and EDS analysis of the test samples at ICB in Dijon. The authors are also grateful to the whole group of LaBoMaP at Arts et Metiers ParisTech of Cluny for their help in the deposition of coatings, the EDS or XRD analyses and residual stresses measurements.

\section{References}

1. A. E. Reiter, V. H. Derflinger, B. Hanselmann, T. Bachmann and B. Sartory: 'Investigation of the properties of $\mathrm{Al}_{1-\mathrm{x}} \mathrm{Cr}_{\mathrm{x}} \mathrm{N}$ coatings prepared by cathodic arc evaporation', Surf. Coat. Technol., 2005, 200, (7), 2114-2122.

2. G. Kim, B. Kim, S. Lee and J. Hahn: 'Structure and mechanical properties of $\mathrm{Cr}-\mathrm{Zr}-\mathrm{N}$ films synthesized by closed field unbalanced magnetron sputtering with vertical magnetron sources', Surf. Coat. Technol., 2005, 200, (5-6), 1669-1675.

3. D. G. Sangiovanni, L. Hultman and V. Chirita: 'Super toughening in $\mathrm{B} 1$ transition metal nitride alloys by increased valence electron concentration', Acta Mater., 2011, 59, (5), 2121-2134.

4. Q. Yuexiu, S. Zhang, B. Li, Y. Wang, J. -W. Lee, F. Li and D. Zhao: 'Improvement of tribological performance of $\mathrm{CrN}$ coating via multilayering with VN', Surf. Coat. Technol., 2013, 231, 126-130.

5. W. -D. Münz: 'Large-scale manufacturing of nanoscale multilayered hard coatings deposited by cathodic arc/unbalanced magnetron sputtering', MRS Bull., 2003, 28, (3), 173-179.

6. P. H. Mayrhofer, C. Mitterer, L. Hultman and H. Clemens: 'Microstructural design of hard coatings', Prog. Mater. Sci., 2006, 51, (8), 1032-1114.

7. M. Uchida, N. Nihira, A. Mitsuo, K. Toyoda, K. Kubota and T. Aizawa: 'Friction and wear properties of CrAlN and CrVN films deposited by cathodic arc ion plating method', Surf. Coat. Technol., 2004, 177-178, 627-630.

8. K. Bobzin, N. Bagcivan, M. Ewering, R. H. Brugnara and S. Theiß: 'DC-MSIP/HPPMS $(\mathrm{Cr}, \mathrm{Al}, \mathrm{V}) \mathrm{N}$ and $(\mathrm{Cr}, \mathrm{Al}, \mathrm{W}) \mathrm{N}$ thin films for high-temperature friction reduction', Surf. Coat. Technol., 2011, 205, (8-9), 2887-2892.

9. B. A. Latella, B. K. Gan, K. E. Davies, D. R. McKenzie and D. G. McCulloch: 'Titanium nitride/vanadium nitride alloy coatings: mechanical properties and adhesion characteristics', Surf. Coat. Technol., 2006, 200, 3605-3611.

10. C. Nouveau, M. -A. Djouadi, P. Beer, M. Lambertin, C. Decès-Petit and P. L. Ko: 'Characterization of triode and magnetron-sputtered chromium nitride coatings', Ceramics, 2000, 61, 131-144.

11. A. Patterson: 'The scherrer formula for $\mathrm{x}$-ray particle size determination', Phys. Rev., 1939, 56, (10), 978-982.

12. G. Stoney: 'The Tension of Metallic Films Deposited by Electrolysis', Proceeding of the Roval Societv of London, 1909, A82, 172-175.

13. K. -W. Wang, T. -N. Lin and D. -Y. Wang: 'Tribological property enhancement of $\mathrm{CrN}$ films by metal vapor vacuum arc implantation of vanadium and carbon ions', Thin Solid Films, 2008, 516, (6), 1012-1019.

14. S. K. Pradhan, C. Nouveau, A. Vasin and M. -A. Djouadi: 'Deposition of $\mathrm{CrN}$ coatings by PVD methods for mechanical application', Surf. Coat. Technol., 2005, 200, (1-4), 141-145.

15. L. Hultman: 'Thermal stability of nitride thin films', Vacuum, 2000 57, (1), 1-30.

16. H. C. Barshilia, N. Selvakumar, B. Deepthi and K. S. Rajam 'A comparative study of reactive direct current magnetron sputtered CrAlN and CrN coatings', Surf. Coat. Technol., 2006, 201, (6), 2193-2201.

17. S. Mahieu, P. Ghekiere, D. Depla and R. De Gryse: 'Biaxial alignment in sputter deposited thin films', Thin Solid Films, 2006 , 515, 1229-1249.

18. S. Ortmann, A. Savan, Y. Gerbig and H. Haefke: 'In process structuring of $\mathrm{CrN}$ coatings, and its influence on friction dry and lubricated sliding', Wear, 2003, 254, 1099-1105.
19. R. Lohmann, E. Osterschulze, K. Thoma and H. Gartner: 'Analysis of r.f.- sputtered $\mathrm{TiB}_{2}$ hard coatings by means of X-ray diffractometry and Auger electron spectroscopy', Mater. Sci. Eng. A, 1991, A139, 259-263.

20. J. H. Ouyang and S. Sasaki: 'The friction and wear characteristics of cathodic arc ion-plated $(\mathrm{V}, \mathrm{Ti}) \mathrm{N}$ coatings in sliding against alumina ball', Wear, 2004, 257, (7-8), 708-720.

21. J. -W. Lee, S. -K. Tien, Y. -C. Kuo and C. -M. Chen: 'The mechanical properties evaluation of the $\mathrm{CrN}$ coatings deposited by the pulsed DC reactive magnetron sputtering', Surf. Coat. Technol., 2006, 200, (10 SPEC. ISS.), 3330-3335.

22. W. Y. Yeung, S. N. Dub, R. Wuhrer and Yu. V. Milman: 'A nanoindentation study of magnetron Co-sputtered nanocrystalline ternary nitride coatings', Sci. Sintering, 2006, 38, (3), 211-221.

23. J. Lin, W. D. Sproul, J. J. Moore, S. Lee and S. Myers: 'High rate deposition of thick $\mathrm{CrN}$ and $\mathrm{Cr}_{2} \mathrm{~N}$ coatings using modulated pulse power (MPP) magnetron sputtering', Surf. Coat. Technol., 2011, 205, 3226-3234.

24. H. Gueddaoui, G. Schmerber, M. Abes, M. Guemmaz and J. C. Parlebas: 'Effects of experimental parameters on the physical properties of non-stoichiometric sputtered vanadium nitrides films', Catal. Today, 2006, 113, (3-4), 270-274

25. R. Hübler: 'Transition metal nitrides thin films deposition using a dynamically controlled magnetron sputtering apparatus', Surf. Coat. Technol., 2002, 158-159, 680-684.

26. W. -G. Jiang, J. -J. Su and X. -Q. Feng: 'Effect of surface roughness on nanoindentation test of thin films', Eng. Fract. Mech., 2008, 75, (17), 4965-4972.

27. J. Luo and R. Steven: 'Porosity-dependence of elastic moduli and hardness of 3Y-TZP ceramics', Ceram. Int., 1999, 25, (3), 281-286

28. K. D. Bouzakis, S. Hadjiyiannis, G. Skordaris, I. Mirisidis, N. Michailidis, K. Efstathiou, E. Pavlidou, G. Erkens, R. Cremer, S. Rambadt and I. Wirth: 'The effect of coating thickness, mechanical strength and hardness properties on the milling performance of PVD coated cemented carbides inserts', Surf. Coat. Technol., 2004, 177-178, 657-664.

29. Q. N. Meng, M. Wen, C. Q. Qu, C. Q. Hu and W. T. Zheng: 'Preferred orientation, phase transition and hardness for sputtered zirconium nitride films grown at different substrate biases', Surf. Coat. Technol, 2011, 205, (8-9), 2865-2870.

30. J. -W. Lee, S. -T. Chang, H. -W. Chen, C. -H. Chien, J. -G. Duh and C. -J. Wang: 'Microstructure, mechanical and electrochemical properties evaluation of pulsed DC reactive magnetron sputtered nanostructured $\mathrm{Cr}-\mathrm{Zr}-\mathrm{N}$ and $\mathrm{Cr}-\mathrm{Zr}-\mathrm{Si}-\mathrm{N}$ thin films', Surf. Coat. Technol., 2010, 205, (5), 1331-1338.

31. N. M. G. Parreira, N. J. M. Carvalho, F. Vaz and A. Cavaleiro: 'Mechanical evaluation of unbiased W-O-N coatings deposited by d.c. reactive magnetron sputtering', Surf. Coat. Technol., 2006, 200, (22-23), 6511-6516.

32. A. R. Shetty, A. Karimi and M. Cantoni: 'Effect of deposition angle on the structure and properties of pulsed-DC magnetron sputtered TiAlN thin films', Thin Solid Films, 2011, 519, (13), $4262-4270$

33. Z. B. Zhao, Z. U. Rek, S. M. Yalisove and J. C. Bilello: 'Phase formation and structure of magnetron sputtered chromium nitride films: In-situ and ex-situ studies', Surf. Coat. Technol., 2004, 185, (2-3), 329-339.

34. Z. G. Zhang, O. Rapaud, N. Bonasso, D. Mercs, C. Dong and C. Coddet: 'Control of microstructures and properties of dc magnetron sputtering deposited chromium nitride films', Vacuum, 2008, 82, (5), 501-509.

35. K. Sarakinos, J. Alami, D. Severin, P. M. Karimi and M. Wuttig: 'The effect of the backscattered energetic atoms on the stress generation and the surface morphology of reactively sputtered vanadium nitride films', Thin Solid Films, 2008, 516, (14), 4568-4573.

36. N. Fateh, G. A. Fontalvo, G. Gassner and C. Mitterer: 'The beneficial effect of high-temperature oxidation on the tribological behaviour of V and VN coatings', Tribol. Lett., 2007, 28, (1), 1-7.

37. M. Polok-Rubiniec, L. A. Dobrzañski and M. Adamiak: 'Comparison of the PVD coatings', Arch. Mater. Sci. Eng., 2009, 38, (2), 118-125.

38. G. S. Kim and S. Y. Lee: 'Microstructure and mechanical properties of AlCrN films deposited by CFUBMS', Surf. Coat. Technol., 2006, 201, (7), 4361-4366.

39. H. Yoshida, K. Kusama, H. Kobayashi and G. Wolf: 'Method to improve scuffing resistance of nitrided rings', in 'Proc. 6th Int. Mobility Technology Conf. and Exhibit (SAE BRASIL 97), Sao Paulo, Brazil', 90557; 1997. 